\title{
地盤環境振動対策への ハイブリッド振動遮断壁の適用性に関する考察
}

\author{
櫛原 信二 1 ・大塚 誠 2 ・深田 久 3 ・早川 清4 \\ 1正会員 株式会社不動テトラ 技術開発統轄部（†103-0016 東京都中央区日本橋小網町7-2） \\ E-mail : shinji.kushihara@fudotetra.co.jp \\ 2正会員 株式会社不動テトラ 技術開発統轄部（テ103-0016 東京都中央区日本橋小網町7-2） \\ E-mail : makoto.otsuka@fudotetra.co.jp \\ 3正会員 株式会社不動テトラ 建設本部地盤技術部（†103-0016 東京都中央区日本橋小網町7-2） \\ E-mail : hisashi.fukada@fudotetra.co.jp \\ 4フェロー会員 立命館大学教授 理工学部環境システム工学科（テ525-8577 滋賀県草津市野路東1-1-1） \\ E-mail : kiyoshi@se.ritsumei.ac.jp
}

\begin{abstract}
ガスクッションを用いたハイブリッド振動遮断壁工法は，振動対策の一つである伝搬経路対策として， 地盤中に空溝を志向した三重構造（ガスクッション十ソイルセメント壁十鋼矢板）の防振壁を構築する技 術である. 本工法は，伝搬経路対策としては最も効果的な空溝とほぼ同等の防振効果が期待できるととも に，地盤条件，施工スペース，空頭制限などに応じて最適な施工方法が選択できる.

本論文では，施工スペースや空頭制限に厳しい制約がない場合に適用できる施工方法について述べると ともに，起振機振動および交通振動を対象とした現場計測結果に基づいて，ハイブリッド振動遮断壁の防 振性能（振動低減効果, 回折波の影響範囲など）について考察した。
\end{abstract}

Key Words : gas cushion, ground vibration, vibration isolation wall, field measurement, numerical analysis

\section{1. はじめに}

近年求められている生活環境の改善問題の一つに地盤 環境振動問題がある.これは，道路・鉄道などの交通振 動，工場などの機械振動，建設作業振動などを発生源と する地盤環境振動（公害振動とも言う）が，地盤内に波 動となって拡散し，周辺の住民に心理的・生理的影響を 与えたり, 建築物・精密機器などに物理的影響を及ぼす 問題を言う。地盤環境振動問題は，比較的軟弱な地盤で 発生しや寸いと考えられている.

実際の振動は様々な周波数からなっており，対象とす る振動の周波数範囲をいくつかの周波数帯域に分けて考 えることが多い，例えば，道路交通振動に関して言えば， 平面道路から発生する振動はほとんどが100Hz以下で10 〜20Hzが中心であり ${ }^{1)}$, 高架道路では高架橋を介して $5 \mathrm{~Hz}$ 以下の低周波成分が卓越するケースも多い22．また， 在来線鉄道振動の卓越周波数は，10Hz付近と63Hz付近 にあることが多い2．一般に，地盤環境振動で扱われる 周波数領域は1〜100Hz程度と言われている.
地盤環境振動対策には，1) 振動の発生源における対策, 2) 振動の伝搬経路における対策，3) 振動の受振部におけ る対策，が考えられる．特に，伝搬経路対策に関しては， 防振溝（空溝）や防振壁（地中壁）などを設けて振動を 遮断する方法が考えられ，その防振効果に関する研究は 古くから行われている3)。このうち, 最も高い防振効果 が期待できるのは十分な深さを有する空溝であるが，安 全性や維持管理面に課題があり, あまり現実的な対策と は言えない. そのため, 各種の地中壁についての研究が 多くなされてきており，一例として，鋼矢板4), 5)，コン

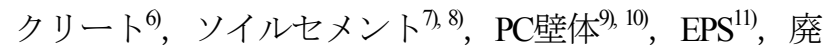
タイヤ (2)などが挙げられる。しかし，地中壁については， 高周波振動に対してはある程度の防振効果が期待できる ものの，公害振動と呼ばれる低周波振動に対してはあま り期待できないことが多い ${ }^{13)}$. また, 地中壁の防振効果 の表れ方は, 地盤条件や振動の周波数特性, あるいは地 中壁の材質, 規模, 位置などに大きく依存し複雑なため, その防振効果を定量的に評価する簡便な手法はまだ確立 されていないのが現状である ${ }^{14)}$. 一方, 空溝については, 
対象となる波長の $1 / 2$ 程度以上の深さを確保できれば, 低周波振動に対しても防振効果は高いと考えられるが, 深い位置までの施工が困難であり，上述したように，溝 の養生方法やメンテナンス，地震時を含めた長期的安全 性に問題があり，恒久的対策としては課題が多い.

そこで，これらの課題を解決すべく，「ガスクッショ ン」と呼ばれる振動遮断材料をソイルセメント壁で被う ことにより, 空溝に近い性能を有寸る防振壁（空溝志向 型地中壁）が，1980年代にスウェーデンのMassarsch ${ }^{155,16}$ によって提案されている. 以来, ガスクッションは，ヨ 一ロッパにおいて数例の適用実績を重ねてはいるものの, 非常に柔軟かつ軽量で気密性を要する材料であるため地 中への設置が難しく, 施工方法に関してはかなりの改 良・改善が図られてきた.

筆者らはこのガスクッションに着目し，我が国の地盤 環境にも適用できる振動対策技術の開発を進めている. すなわち，上記防振壁に鋼矢板を付加した「ハイブリッ ド振動遮断壁」17, 18) 考案し, 高架橋の下など空頭制限 のある狭监地においても安全に構築できる施工方法を既 に開発している，なお，鋼矢板については，当初は隣接 する重要構造物の施工時安全性や地震時を含めた長期的 安全性の確保が一義的な役割であると考えていたが，そ の後の研究 ${ }^{19}, 20$, 21)により, 鋼矢板の岡性が振動遮断壁自 体の変形を抑制し，振動低減効果にも大きく寄与寸るこ とが明らかとなった。

本論文では，まずハイブリッド振動遮断壁の概要を示 し，上述した開発当初の施工方式（以下，狭险地対応型 と呼ぶ） とは別に新たに開発した施工方式，すなわち施 工スペースや空頭制限に厳しい制約がない場合に適用で きる施工方法（以下，標準施工型と呼ぶ）について述心゙ る. 次に, 標準施工型で設置したハイブリッド振動遮断 壁の防振効果を検証するため, 可変式起振機（加振周波 数6〜25Hz) による現場計測を実施し，その効果が空溝 とほぼ同等であることなどを確認するとともに，二次元 数值解析を用いて防振性能評価を行った. さらに, 交通 振動（在来線鉄道振動）を対象とした現場計測結果より, 比較的高周波の振動（卓越周波数 $20 \sim 60 \mathrm{~Hz}$ 付近）に対す るハイブリッド振動遮断壁の防振効果, ならびに遮断壁 端部からの回折波による影響範囲について考察する.

\section{2. ハイブリッド振動遮断壁の概要}

\section{(1) 防振構造}

ハイブリッド振動遮断壁の構造概念図を図-1に示す. 本遮断壁は, 空溝を志向した三重構造（ガスクッション 十ソイルセメント壁十鋼矢板）の防振壁であり, 空溝と

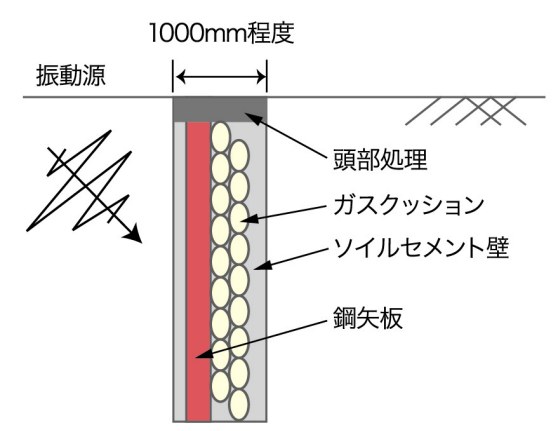

図-1 ハイブリッド振動遮断壁の構造概念図

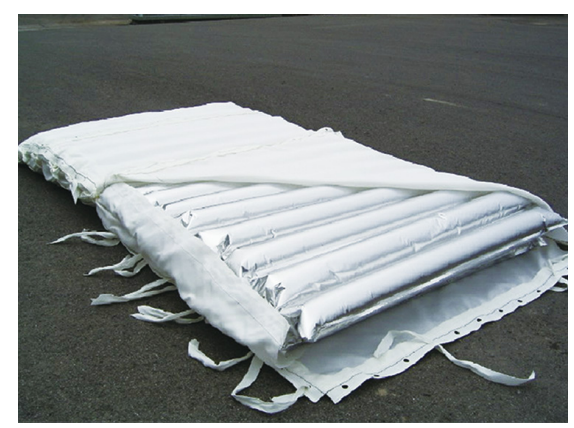

写真-1 ガスクッションと保護カバー

地中壁の長所を併せ持つ. 寸なわち, 空溝とほぼ同等の 防振効果が期待でき, かつ長期的安全性も確保できるメ ンテナンスフリーの防振壁である. 各構成部材の役割を 以下に示す.

\section{a) ガスクッション}

ガスクッションの役割は, 地中壁内に空隙部を連続的 に形成し, 空溝の状態に近づけることである.ガスクッ ションは，アルミニウムを主体とする材質（ラミネート 構造) で, 直径 $10 \mathrm{~cm}$ のューブからなるパネルの2層構 造となっている，また，施工時には，破損防止のため保 護カバーを取付ける（写真-1参照）。

\section{b) ソイルセメント壁}

ソイルセメント壁の役割は, ガスクッションによる空 隙部をセメントベントナイトで保護し，土圧（常時・地 震時）に耐える構造とすることである.

\section{c) 鋼矢板}

鋼矢板の役割は，振動遮断壁の岡性（防振効果）を増 大させること, 隣接構造物の地震時を含めた長期的な安 全性を確保すること，ガスクッションの浮上りを防止す ること，などである．鋼矢板は，防振効果の面から振動 発生源側に配置することを原則とする.

\section{d) 頭部処理}

頭部処理の役割は, 振動の伝搬を極力抑え, かつ安全 性（人・車両の通行時）を確保することである. 


\section{(2) 施工方法}

ハイブリッド振動遮断壁の施工方法は，大きく2種類 (標準施工型，狭险地対応型）に分類される，なお，施 工限界深度は，現在のところ15m程度である.

\section{a) 標準施工型}

標準施工型の施工概念図を図-2に示す，施工スペース や空頭制限に厳しい制約がない場合には, 標準施工型が 適用でき, 経済的に有利となる。 また, 施工深度や土層 構成などに応じて, 最適な掘削機 (バックホウ, TRD, オールケーシング掘削機，掘削専用機など）を使用する. 標準施工型の施工手順を以下に示寸.

1) バックホウなどにより溝を掘削し, 溝壁維持のた め特殊に配合した泥水を注入する。

2) クレーンにより，鋼矢板と一体化させたガスクッ ションを掘削溝に建込む.

3） ガスクッションの周囲にセメント混合土を充填す る. 2) 3) で発生する余剩泥水はポンプで汲上げ, 再利用もしくは処分する.

4）頭部処理を施し，振動遮断壁が完成する.

標準施工型では，泥水で満たされた溝中に，鋼矢板の 自重により，鋼矢板とガスクッションを所定の深度まで 挿入するため, 掘削時に溝壁の安定（崩壊防止）を図る ことが極めて重要である，そこで，掘削時には，溝壁の 安定が確保できるよう，高分子系増粘材を添加した特殊 泥水を使用する．詳細については，3.(3)に後述する.

\section{b) 狭隘地対応型}

狭隘地対応型の施工概念図を図-3に示寸，高架橋の下 など施工スペースや空頭制限に厳しい制約がある場合に は，狭险地対応型を適用寸る，狭险地対応型の施工手順 を以下に示す.

1) バックホウにより, 排泥回収用のガイド溝を掘削 する.

2）油圧式杭圧入引抜機（サイレントパイラー）によ り，鋼矢板を圧入する.

3）専用機を用いて, 多軸摇動ジェットによる地盤切 削およびソイルセメント壁造成を行うと同時に, 油圧式押込装置によりガスクッションを挿入する. 必要に応じて, 継打ち施工を行う。なお，発生す る排泥はポンプで汲上げ，処分する.

4) 頭部処理を施し，振動遮断壁が完成する.

狭险地対応型では，専用機が鋼矢板上を移動して施工 を行うため，鋼矢板には根入れ部を設け，施工機の支持 力を確保する必要がある. 寸なわち, 鋼矢板の設置深度 は, ガスクッションよりも深い位置とする.

また，実際に高架橋沿線下で狭险地対応型を適用する 場合には，近接施工になるため，防振効果はもとより， 施工時における隣接構造物の安全性確保が重要な要素と

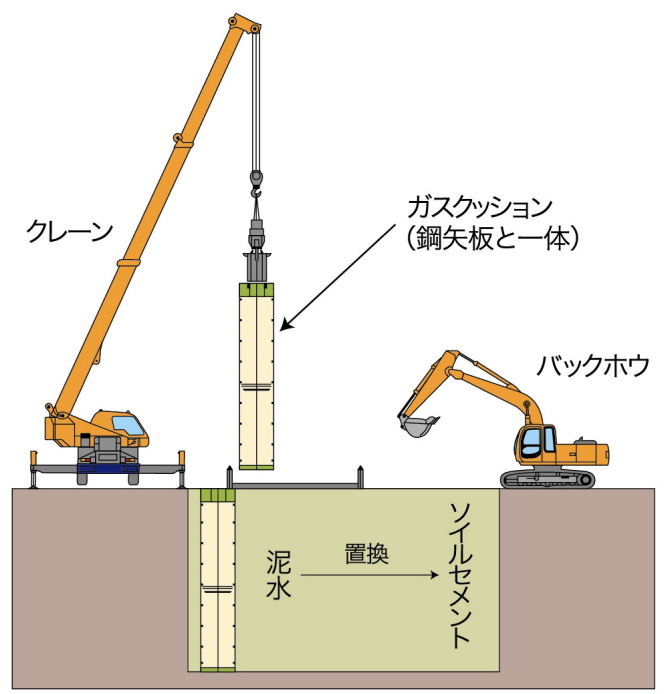

図-2 標準施工型の施工概念図

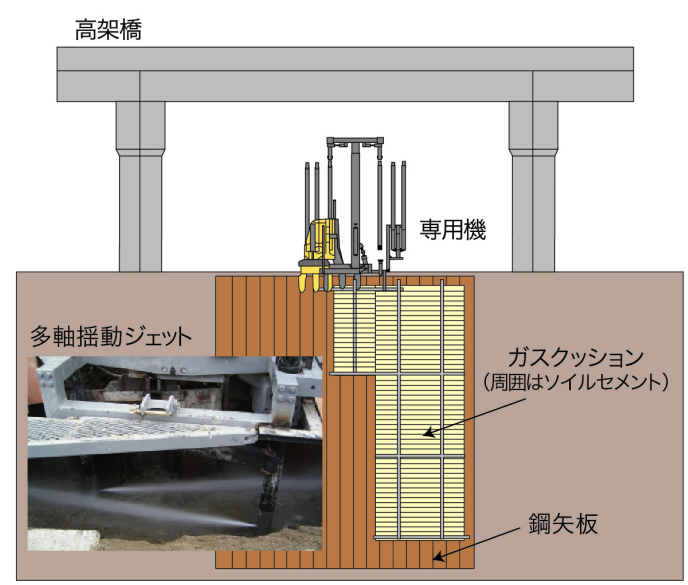

図-3 狭险地対応型の施工概念図

なる，狭隘地対応型では，施工時に変位計測を実施し， 施工時における周辺地盤への変位による影響がほとんど ないことを確認している22).

\section{3. 標準施工型の施工事例}

\section{(1) 試験工事と本工事}

工場から発生する振動の低減を目的として，群馬県内 の工場敷地内において，ハイブリッド振動遮断壁の設置 工事を行った．本事例では，まず試験工事区間において ハイブリッド振動遮断壁を設置し，可変式起振機を用い た防振性能確認試験により，その効果を検証した．起振 機試験の内容と結果については，4.に後述する. 工事箇 所の地盤概要と試験工事区間の遮断壁仕様を図-4に示す. 
対象地盤は, 深度7.5mまではシルト・砂・碩を主体とし た比較的軟弱な地盤（N值=0１2）であるが，それ以深 は硬質な礫混じり玉石層（N值>50）であった。 ハイブ リッド振動遮断壁は，この玉石層に $2.5 \mathrm{~m}$ 根入れするよう に深度 $10 \mathrm{~m}$ で設置し，その施工延長は20mとした。

その後, 試験工事区間での起振機試験結果を踏まえ, 振動解析などにより工場振動に対する防振効果について 検討した．その結果，本工事区間でのハイブリッド振動 遮断壁仕様は，費用対効果を考慮し，設置深度を $7.5 \mathrm{~m} に$ （玉石層上端まで），施工延長を84.5mに決定した。

\section{(2) ハイブリッド振動遮断壁の施工}

施工方法は標準施工型を採用した（写真-2参照）。ま た，施工箇所近傍には在来線鉄道軌道があり，施工時に 変位計測を実施したが，敷地境界付近で水平変位 $1 \mathrm{~mm}$ 程 度と有意な変位は認められず，標準施工型においても， 周辺地盤への変位による影響のないことが確認された。 各施工過程の詳細を以下に示す。

\section{a) 溝掘削 $\cdot$ 泥水注入}

試験工事区間では，玉石層を掘削するため，オールケ ーシング掘削機を用いた．掘削仕様は，ケーシング径 $\phi$ $1500 \mathrm{~mm}$, ピッチ $1000 \mathrm{~mm}$ とし, 掘削幅 $1000 \mathrm{~mm}$ を確保し た. 所定の深度まで掘削した後，ケーシング内に泥水を 注入し, ケーシングを引抜いた後の掘削溝壁の崩壊を防 いだ. なお，本工事区間では，玉石層を掘削しないため， バックホウ $\left(0.7 \mathrm{~m}^{3}\right.$ ，スライドアーム仕様機）を用いて 溝掘削を行った.

\section{b) ガスクッション挿入（鋼矢板を含む）}

鋼矢板（幅 $400 \mathrm{~mm} \times 3$ 枚）とガスクッション（幅 $1300 \mathrm{~mm} ） を 一$ 体化させ，クレーンにより泥水中に鉛直 に挿入した。また，鋼矢板には予めジョイント部

（100mm）を溶接しておき，延長方向に隙間なく接合で きる構造とし，振動遮断壁としての連続性を確保した (図-5参照)．なお，鋼矢板は，試験工事区間ではIII型 を用いたが，本工事区間では，防振効果に及ぼす影響を 検討したうえで，経済性を考慮しI型を使用した.

\section{c) ソイルセメント壁造成（セメント混合土充填）}

試験工事区間では，車上プラントにてセメントスラリ 一を製造し，掘削溝より汲上げた泥水と混合させ，コン クリートポンプにて掘削溝中に打設した. ソイルセメン 卜の目標強度は, 一軸圧縮強さ $100 \mathrm{kN} / \mathrm{m}^{2}$ (原地盤強度と 同程度）であるが，サンプリングした試料は目標強度を 十分に満足する值であった，なお，本工事区間では，掘 削土に水・セメントを混合して流動化処理土（固化材添 加量 $100 \mathrm{~kg} / \mathrm{m}^{3}$ 程度）を製造し，掘削溝中に打設した．す なわち, 溝掘削で発生した土砂を有効利用寸ることで, 掘削土の処分量を抑制した.

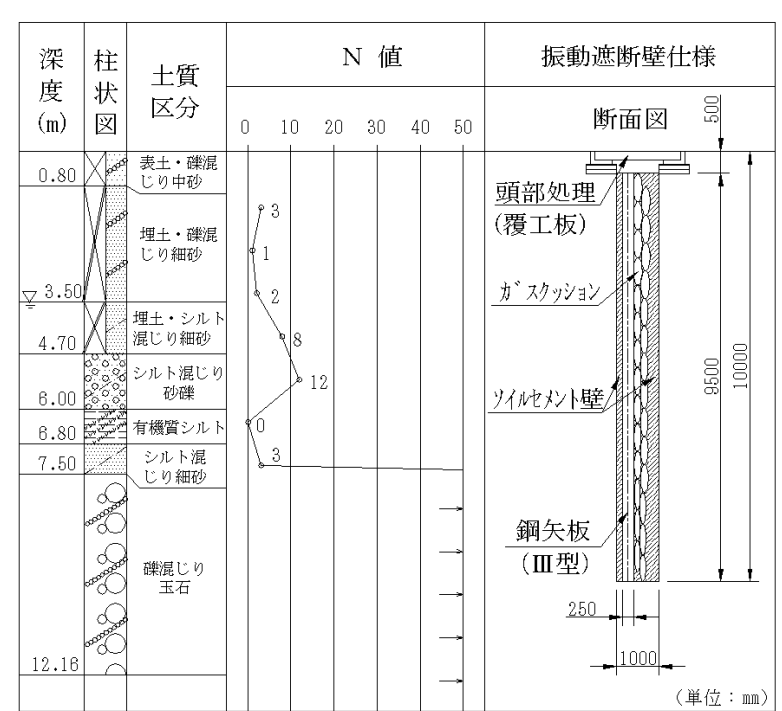

図-4 地盤概要と振動遮断壁仕様（試験工事区間）

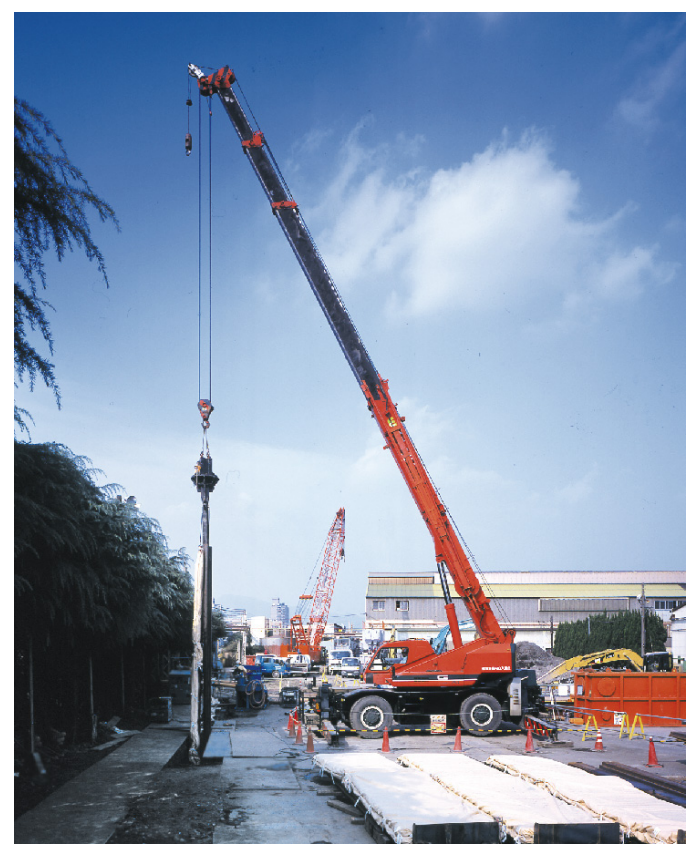

写真-2 ハイブリッド振動遮断壁の設置状況

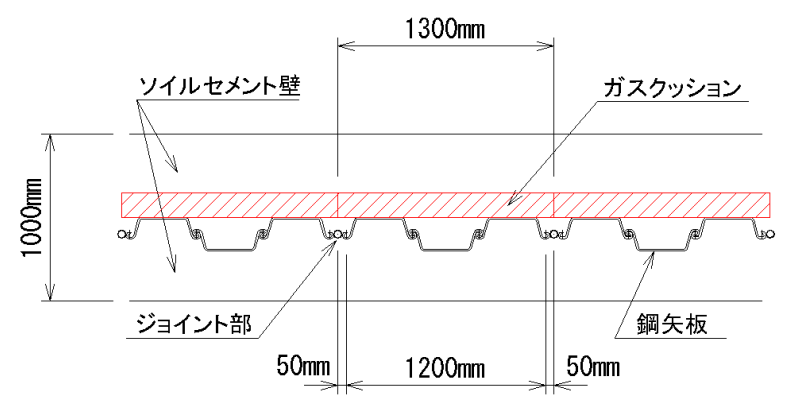

図-5 ガスクッション配置 


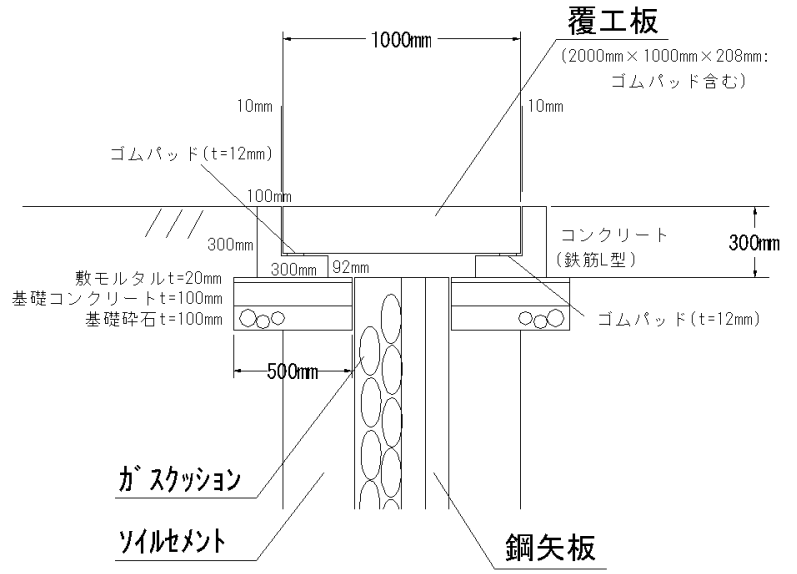

図-6 頭部処理仕様

\section{d) 頭部処理（覆工板設置）}

頭部処理には覆工板を用い，振動遮断壁上部の利用 （人・車両の通行など）と振動遮断壁の保護を兼ねた. また，覆工板を通して振動が伝搬しないように，覆工板 下には空洞を設け，鉄筋コンクリート製の受台との間に は防振ゴムを取付けるなどの工夫を施した（図-6参照）。

\section{(3) 泥水による掘削溝壁の安定}

当該地盤は砂・碩・玉石層が大部分を占め，透水係数 が大きい. そのため, 安定液として通常のベントナイト 泥水 ${ }^{23}$ を用いると，逸泥による水位低下のため，溝壁崩 壊の危険性が高いと判断した。 そこで，近年実績を増や しつつある，崩壊性地盤における泥水シールド工法の逸 泥対策 ${ }^{24}$ に着目し，高分子系増粘材と粒度調整用の粉末 粘土を配合した特殊なベントナイト泥水を使用すること とした．泥水の配合仕様を表-1に示寸，泥水は，現地に 設置したプラントにより製造した．泥水による溝壁安定 の概念図を図-7に示す，溝内に投入された泥水は，溝壁 からある範囲まで地盤中に浸透し，土粒子との付着およ び目詰まりにより，溝壁面に速やかに難透水性の泥膜を 形成する．良好な泥膜が形成されると，泥水圧が溝壁面 に有効に作用し，溝壁の安定が図られる，才なわち，本 泥水の粘性と泥水中の固形分による地盤間隙閉塞効果が, 溝壁の崩壊防止に大きく寄与するものと考えた.

また，ガスクッションを泥水中に挿入する際，あるい は泥水中にセメント混合土を充填する際は, 余剩泥水が 発生する. 当工事では，この余剩泥水をポンプで汲上げ 貯蔵して再利用することで，泥水の製造量および処分量 の低減を図った。しかしながら，再利用の過程において， 泥水に掘削土（砂分）やセメントなどが混入すると，比 重, 粘性, $\mathrm{pH}$, カルシウムイオンなどが変化し, 泥水 性能の低下（劣化）による地盤崩壊を招く恐れがある. そこで，回収した泥水に新規に作成した泥水を混合する
表-1 泥水の配合仕様（泥水 $1 \mathrm{~m}^{3}$ 当たり）

\begin{tabular}{c|c|c|c}
\hline ベントナイト & 粉末粘土 & 高分子系増粘材 & 水 \\
\hline \hline $100 \mathrm{~kg}$ & $150 \mathrm{~kg}$ & $150 \mathrm{cc}$ & $900 \mathrm{~kg}$ \\
\hline
\end{tabular}

表-2 泥水性状に関する試験結果

\begin{tabular}{l|c|c}
\hline \multicolumn{1}{c|}{ 試験項目 } & 新規作成泥水 & 再利用泥水 \\
\hline \hline 比重 & 1.15 & 1.08 \\
\hline ファンネル粘度 $(\mathrm{sec})$ & 47.5 & 27.8 \\
\hline イールドバリュー $(\mathrm{Pa})$ & 9.4 & 1.5 \\
\hline $\mathrm{pH}$ 值 & 9.4 & 9.6 \\
\hline ろ水量 $(\mathrm{ml})$ & 15.0 & 18.4 \\
\hline
\end{tabular}

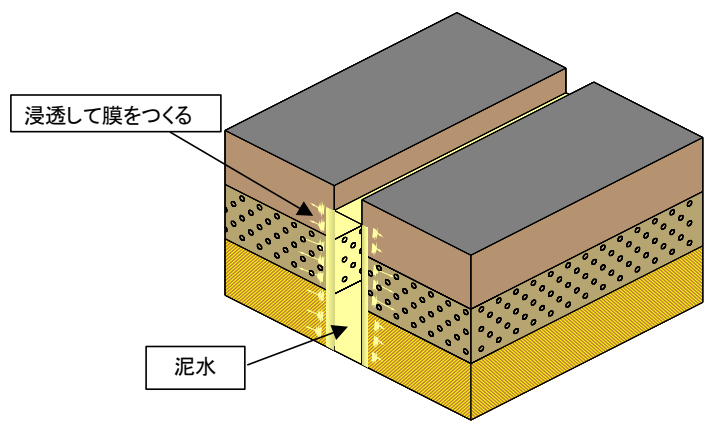

図-7 泥水による溝壁安定の概念図

ことにより，泥水全体の性状改善を図った，泥水性状に 関する各種試験 ${ }^{25}$ の結果を表-2に示す。当該地盤では, 表中の再利用泥水を用いても, 溝壁の安定が確保され, 障害物に当ることなく遮断材を所定の深度に設置できた. 泥水の使用に当たっては, 地盤条件や利用状況に応じ て, 配合量を調整し, 泥水性状の管理值を適切な範囲に 設定する必要がある，例えば，「溝壁の安定性」を保つ には, 高比重・高粘性・少万水量の状態が望ましいが, 粘性が高すぎると，「掘削土との分離性」が悪く，比重 が高くなり，砂分を除去しないと，ガスクッション挿入 時やセメント混合土充填時に支障をきたす可能性がある. 工事期間を通じ，泥水の諸機能を確保寸るには，泥水性 状に関する品質管理を適切に行うことが重要である.

\section{4. 起振機振動を対象とした防振性能確認試験}

\section{(1) 振動計測概要}

標淮施工型で設置したハイブリッド振動遮断壁の防振 効果を検証するため，3.(1)に示した試験工事区間（設置 深度 $10 \mathrm{~m}$ ，施工延長 $20 \mathrm{~m} ）$ において，可変式起振機によ る現場計測を実施した。振動計測位置図を図-8に示す。 振動計測は，遮断壁端部から平面的に回り込んでくる波 （回折波）による影響を極力抑えるため，壁の中央部に 


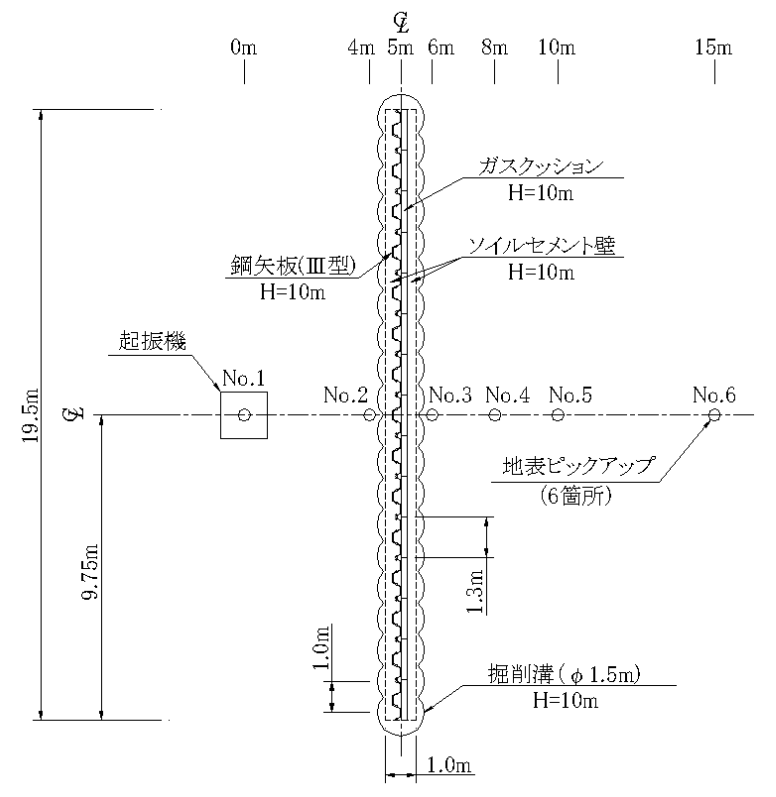

図-8 振動計測位置図（試験工事区間）

計測ラインを設け，壁から5m離れた位置に起振機を設 置し，壁前面2箇所（No.1，No.2）および壁背面4箇所 （No.3〜No.6）の計6箇所に測点を配置した．振動発生 源となる起振機（EX-2000DC，伊藤精機株式会社）は荷 重制御式であり，最大加振力 $60 \mathrm{kN} ， 2 ３ 0 \mathrm{~Hz}$ の正弦加振 が可能な装置である. 試験では加振力を $10 \mathrm{kN}$ 設定し， 加振周波数を $6 \mathrm{~Hz}, 8 \mathrm{~Hz}, 10 \mathrm{~Hz}, 12 \mathrm{~Hz}, 15 \mathrm{~Hz}, 18 \mathrm{~Hz}$, $20 \mathrm{~Hz} ， 23 \mathrm{~Hz} ， 25 \mathrm{~Hz}$ のケースとした. 各周波数で鉛直方 向に連続的に正弦加振し，十分定常状態であることを確 認したうえで計測を行った。計測には振動レベル計

（VM-52，リオン株式会社）を使用し，鉛直方向の振動 加速度を1/500sec間隔で測定した。なお，振動計測は， 遮断壁設置前に1回，設置後に2回（覆工板が無い場合と 有る場合）の計3回実施した.

\section{(2) 振動計測結果}

振動計測結果の一例 $(6 \mathrm{~Hz}, 8 \mathrm{~Hz}, 10 \mathrm{~Hz}, 15 \mathrm{~Hz}, 20 \mathrm{~Hz}$, $25 \mathrm{~Hz})$ を図-9に示す。ここでは，計測された加速度振幅 の最大值から実効值を算出（1/ $\sqrt{2}$ 倍）し，次式により振 動加速度レベルに換算して整理した。

$$
\mathrm{VAL}=20 \log _{10}\left(\frac{\mathrm{A}}{\mathrm{A}_{0}}\right)
$$

ここに,

$$
\text { VAL : 振動加速度レベル }(\mathrm{dB})
$$

A : 加速度実効值 $\left(\mathrm{m} / \mathrm{s}^{2}\right)$

$\mathrm{A}_{0}$ ：基準值 $\left(10^{-5} \mathrm{~m} / \mathrm{s}^{2}\right)$

なお，図-9は起振機直下での振動加速度レベルを基準に， 各測点の計測結果を相対レベルで表した。

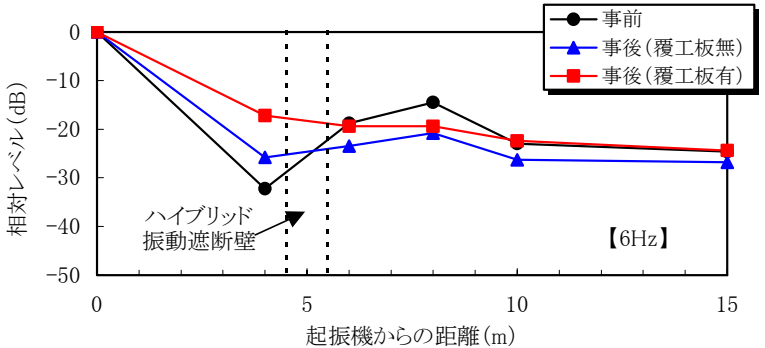

(a) $6 \mathrm{~Hz}$

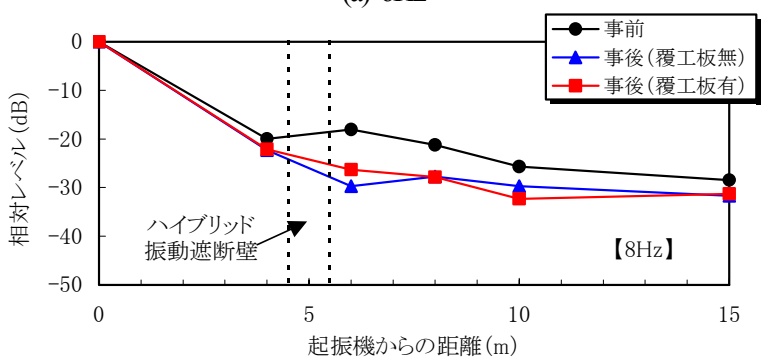

(b) $8 \mathrm{~Hz}$

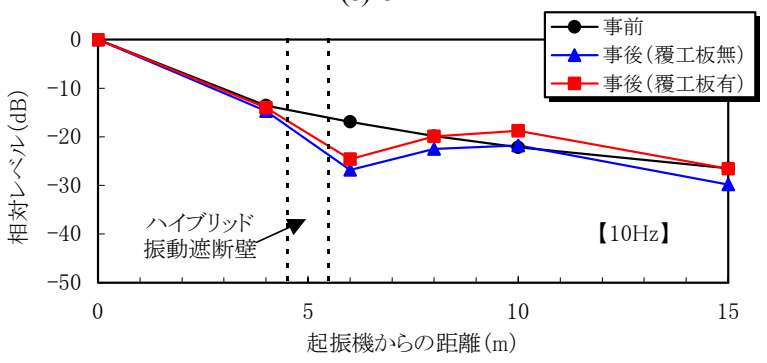

(c) $10 \mathrm{~Hz}$

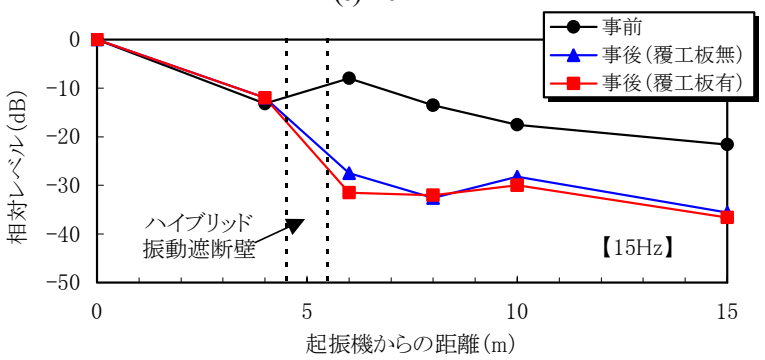

(d) $15 \mathrm{~Hz}$

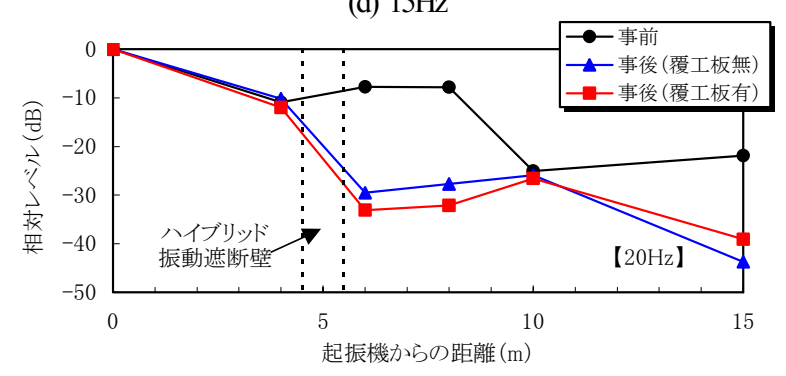

(e) $20 \mathrm{~Hz}$

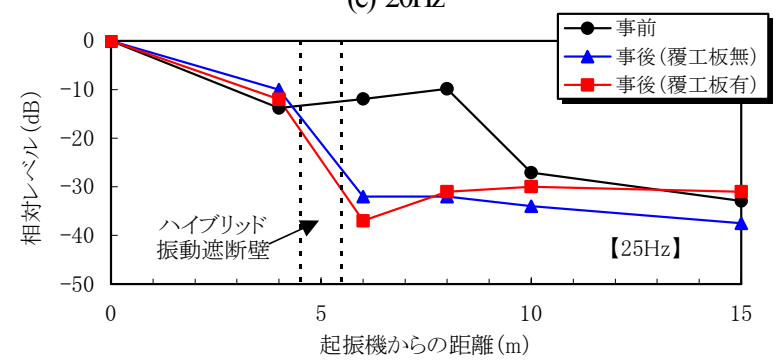

(f) $25 \mathrm{~Hz}$

図-9 振動計測結果 


\section{a) ハイブリッド振動遮断壁の防振効果}

図-9より，壁裏1～3m（振動源から6～8m）では，八 イブリッド振動遮断壁による防振効果がほぼ顕著に表れ ていることがわかる．周波数別にみると，覆工板の有無 により多少の差異はあるものの, 壁裏1mでの振動低減 量（事前一事後）を平均すると，6Hzでは3 $\mathrm{dB}$ 程度，8〜 $10 \mathrm{~Hz}$ では $10 \mathrm{~dB}$ 程度，12Hz以上では20dB程度以上の効果 が得られている．また，壁から距離が離れると防振効果 は減少しているが，これは壁端部からの回折波による影 響が少なからず表れているものと推察する.

\section{b) 頭部処理（覆工板）による影響}

遮断壁の頭部処理に用いた覆工板が，防振効果に及ぼ す影響について考察する．そこで，覆工板の有無により 生じた相対レベルの差（覆工板有一覆工板無）を図-10 に示す．同図より，周波数によって効果が増大あるいは 減少したりしているが，図中の遮断壁背面部におけるプ ロットを平均すると+0.6dBであった。この結果から判断 すると，覆工板を設置することで防振効果が大きく低下 することはないと言える.ただし，周波数によってバラ ツキがあり，特に10Hz以下の低周波域において，3〜 $4 \mathrm{~dB}$ 程度効果が減少している箇所が見受けられることに 留意する必要がある.

頭部処理に関して, 吉岡ら ${ }^{20} か ゙$ 実施した空溝の防振効 果に関する解析結果によれば，10Hz程度以上の比較的 高周波域で防振効果に及ぼす影響が大きいことが示され ている．今回の計測結果は，上記解析結果と必ずしも一 致しているとは言えないが，これは地盤条件や遮断壁仕 様（深度，位置）などの違いが，複雑に影響し合ってい るものと考えられる.

\section{c) 遮断壁設置前の距離減衰特性}

図-9のうち事前の結果のみに着目すると，8～10Hzで は，地盤振動が距離とともにほぼ単調に減衰していく様 子が伺える．しかしながら，6Hzでは，振動源に比較的 近い箇所（4～6m付近）で振動が大きく減衰し，その後 大きく増加する傾向にある，逆に15Hz程度以上になる と，振動源から少し離れた箇所（6〜8m付近）で振動が 増加し，その後また減衰するという，いわゆる振動の波 打ち現象（振動源から離れると，振動が一定の間隔で波 打ちながら減衰していく現象）が生じていると考えられ る.この点に関しては，過去に実施されている起振機実 験でも同様の結果 ${ }^{10}$ が報告されている. これは単一周期 による振動特有の現象であると推察するが，事後の結果 と比較する際には注意する必要がある。すなわち，遮断 壁の設置により波の位相が変化し，設置前は振動が小さ かった箇所でも設置後に大きくなったり，逆に設置前に 大きかった箇所が設置後に小さくなったりする可能性が 考えられる．この場合，見掛け上は，前者では防振効果

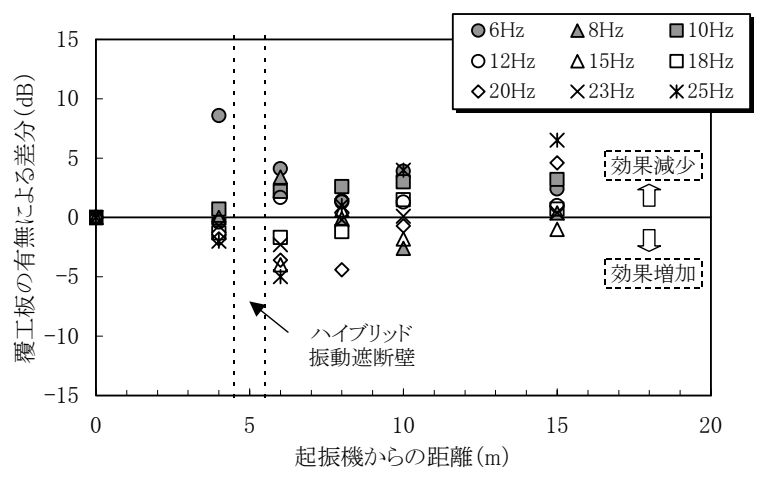

図-10 覆工板の有無が防振効果に及ぼす影響

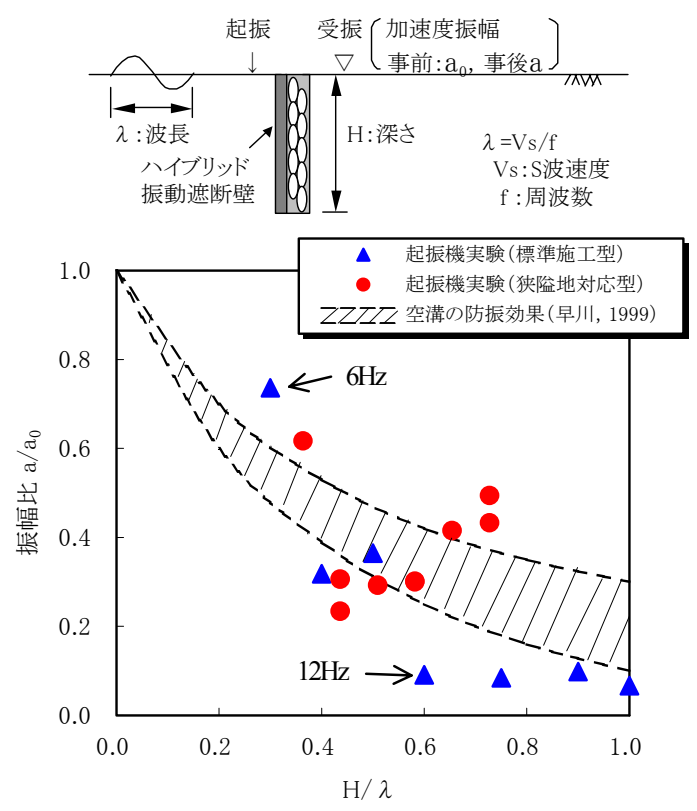

図-11 空溝の防振効果との比較（壁裏 $1 \mathrm{~m}$ )

の減少，後者では防振効果の増加といった形になって現 れてくるものと解釈できる.

\section{(3) 空溝の防振効果との比較}

ハイブリッド振動遮断壁の防振効果を空溝と比較する. そこで，壁端部からの回折波による影響がほとんどない

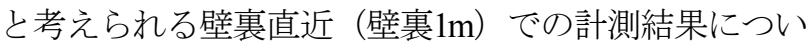
て，加速度振幅比（ $\mathrm{a} / \mathrm{a}_{0} ）$ および壁の深さHと波長 $\lambda$ と の比 $(\mathrm{H} / \lambda)$ の関係で整理し，図-11に示す。なお，波 長については，各土層のS波速度を遮断壁の設置深度相 当で加重平均し，加振周波数で除した值とした。 また， 事後の加速度振幅は, 覆工板の有無による差異を考慮し て両者の平均值とした．同図には，既往の狭险地対応型 での試駼結果 ${ }^{19}$ および空溝の防振効果 ${ }^{3}$ も併せて示した. 同図より，標準施工型で設置したハイブリッド振動遮断 壁の防振効果も，空溝とほぼ同等であることがわかる. 
ただし，6Hzでは空溝の効果よりも小さく，逆に12Hz以 上では空溝の効果よりも大きい（振幅比が小さいほど低 減効果が大きいことになる）結果となっているが，これ は先にも述べたように，遮断壁の設置に伴って位相がず れたことが起因し，見掛け上，防振効果が目減りあるい は上乗せされたものと推察する.

\section{(4) 二次元数值解析による防振性能の評価}

\section{a) 解析条件}

二次元数值解析を活用し，可変式起振機による防振性 能確認試験結果の検証を試夕た．解析には，二次元FEM 地盤解析支援システムの動的解析プログラム（SAMBA， 富士通エフ・アイ・ピー株式会社）を用いた。解析モデ ルを図-12に示す．地盤およびハイブリッド振動遮断壁 を二次元FEMでモデル化し（施工延長は無限長として評 価，覆工板は考慮しない，鉛直方向のメッシュ分割は波 長の $1 / 5$ 程度以下），6〜25Hzを対象に正弦加振（起振機 直下で $\mathrm{VAL}=100 \mathrm{~dB}$ 程度を想定し, 入力加速度は $1 \mathrm{~m} / \mathrm{s}^{2}$ ) を行い，地表面での応答值（振動低減量）を評価した。

解析に用いたパラメーターを表-3に示寸，遮断壁の各

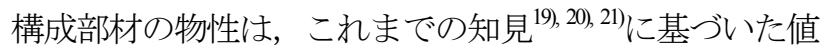

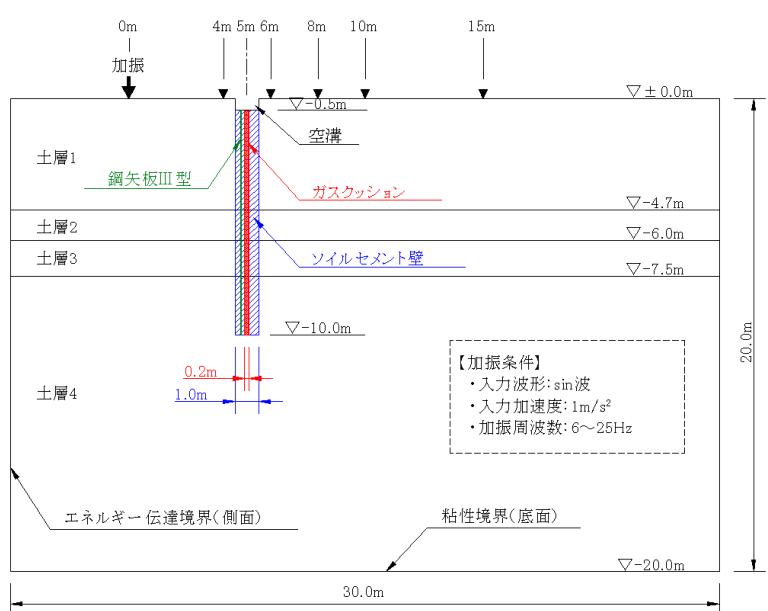

図-12 解析モデル

表-3 解析に用いたパラメーター

\begin{tabular}{|c|c|c|c|c|c|c|}
\hline 平面ひずみ要素 & $\begin{array}{c}\text { 密度 } \\
\rho \\
\left(\mathrm{t} / \mathrm{m}^{3}\right) \\
\end{array}$ & $\begin{array}{c}\text { ポアソン比 } \\
v\end{array}$ & 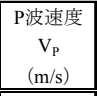 & 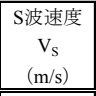 & \begin{tabular}{|c|c|} 
世ん断剛性 \\
$\mathrm{G}$ \\
$\left(\mathrm{kN} / \mathrm{m}^{2}\right)$
\end{tabular} & $\begin{array}{c}\text { 減衰定数 } \\
\mathrm{h}\end{array}$ \\
\hline 土層1:埋土(細砂) & 1.63 & 0.412 & 310 & 120 & 23472 & 0.05 \\
\hline 土層 2 : 砂啋 & 1.93 & 0.494 & 1620 & 170 & 55777 & 0.05 \\
\hline 土層3:シルト & 1.63 & 0.496 & 1540 & 140 & 31948 & 0.05 \\
\hline 土層4:磷混じり玉石 & 2.23 & 0.432 & 2220 & 770 & 1322167 & 0.05 \\
\hline ガスクッション & 0.01 & 0.490 & - & 1 & 0.01 & 0.00 \\
\hline ソイルセメント壁 & 1.20 & 0.200 & - & 200 & 48000 & 0.03 \\
\hline $\begin{array}{l}\text { 基盤層 } \\
\end{array}$ & 2.00 & 0.450 & - & 300 & 180000 & 0.05 \\
\hline 梁要素 & $\begin{array}{c}\text { 密度 } \\
\rho \\
\left(\mathrm{t} / \mathrm{m}^{3}\right) \\
\end{array}$ & $\begin{array}{c}\text { ポアソン比 } \\
v\end{array}$ & \begin{tabular}{|c} 
世ん断岡性 \\
$\mathrm{G}$ \\
$\left(\mathrm{kN} / \mathrm{m}^{2}\right)$
\end{tabular} & $\begin{array}{c}\text { 断面二次 } \\
\text { モーメント I } \\
\left(\mathrm{m}^{4}\right)\end{array}$ & $\begin{array}{c}\text { 断面積 } \\
\text { A } \\
\left(\mathrm{m}^{2}\right) \\
\end{array}$ & $\begin{array}{c}\text { 減衰定数 } \\
\mathrm{h}\end{array}$ \\
\hline 鋼矢板III型 & 7.85 & 0.300 & 81000000 & 0.000164 & 0.0191 & 0.03 \\
\hline
\end{tabular}

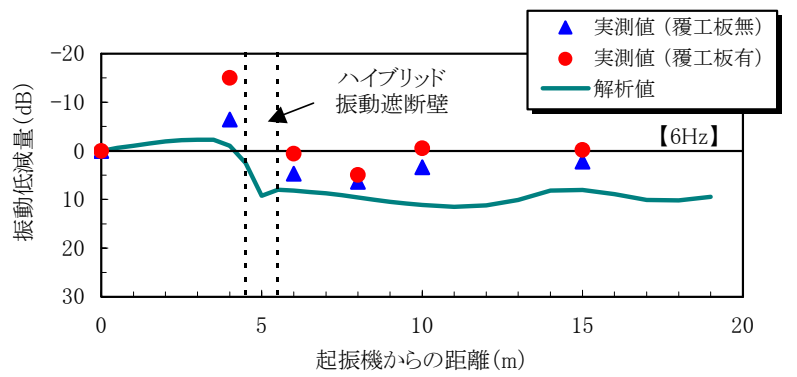

(a) $6 \mathrm{~Hz}$

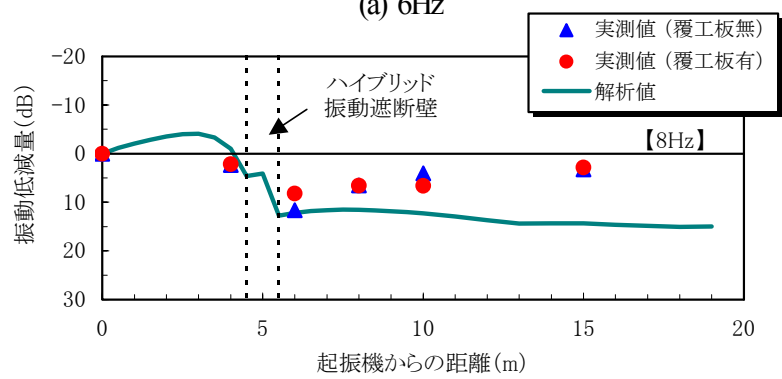

(b) $8 \mathrm{~Hz}$

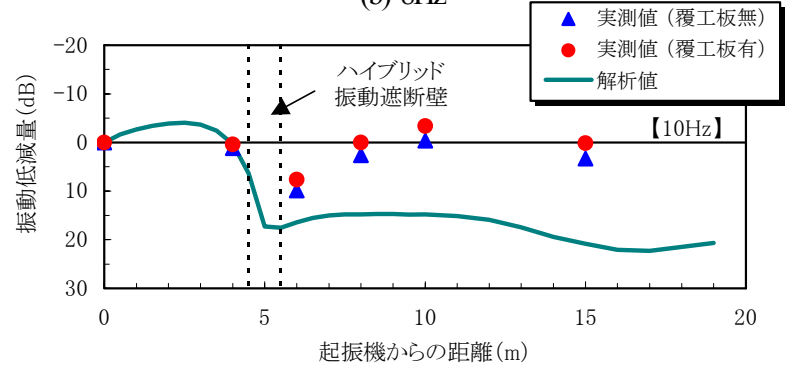

(c) $10 \mathrm{~Hz}$

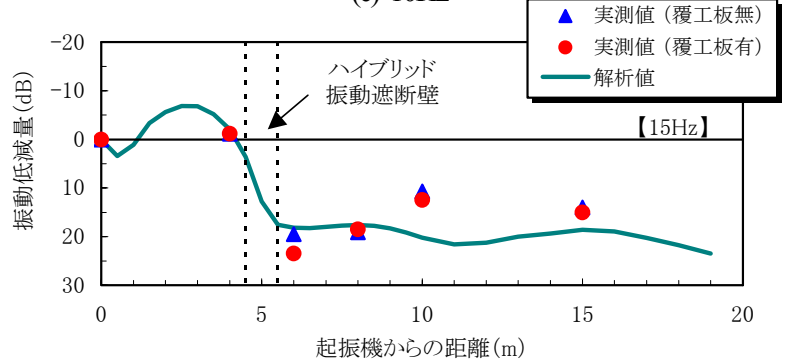

(d) $15 \mathrm{~Hz}$

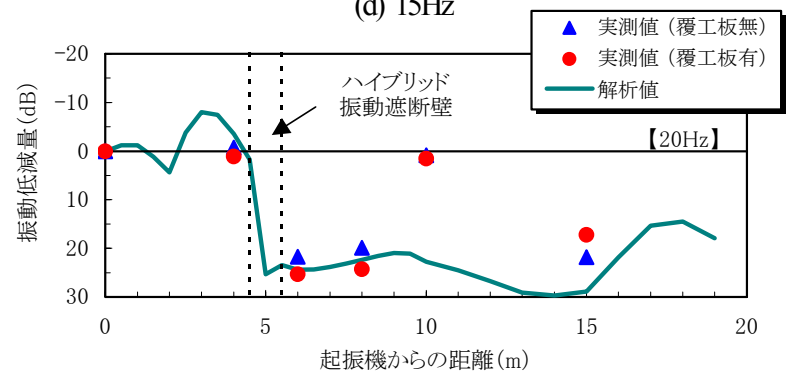

(e) $20 \mathrm{~Hz}$

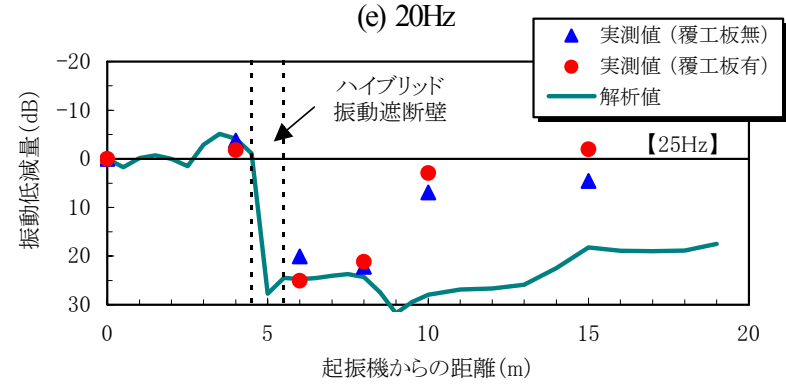

(f) $25 \mathrm{~Hz}$

図-13 振動低減量と距離の関係 


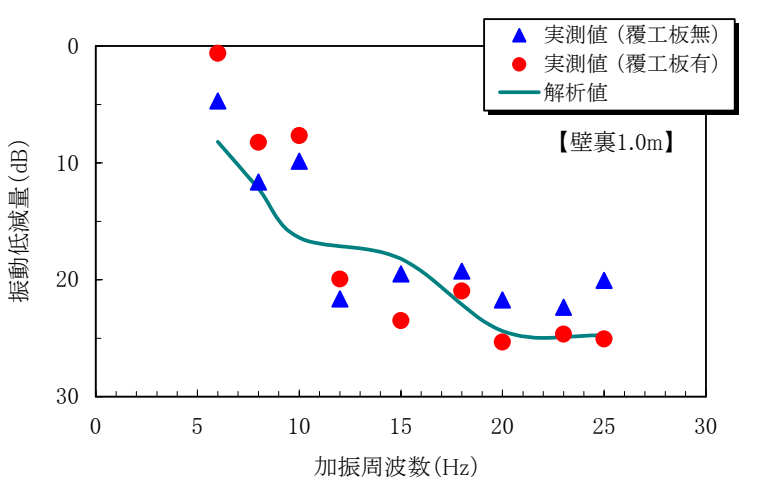

図-14 振動低減量と周波数の関係（壁裏 $1 \mathrm{~m}$ )

であり，特にガスクッション部については空隙であると 仮定し，剛性と質量を非常に小さいものとした．また， 地盤の物性はPS検層結果に基づいて設定した。ただし, 地盤の減衰定数については，土の種類に応じて 1 ～ $10 \%$

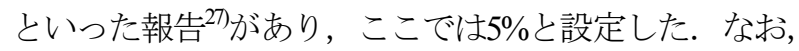
礫混じり玉石層のS波速度 $770 \mathrm{~m} / \mathrm{s}$ は，沖積砂礫層の一般 值250〜 350 m/ $\mathrm{s}^{28)}$ と比較してかなり大きい值であるが，こ れは $\phi 300 \mathrm{~mm}$ 程度の玉石が点在していたためと推察され, 解析結果に及ぼす影響は小さいものと考えられる.

\section{b) 解析結果}

振動低減量と距離の関係 $(6 \mathrm{~Hz}, 8 \mathrm{~Hz}, 10 \mathrm{~Hz}, 15 \mathrm{~Hz}$, $20 \mathrm{~Hz} ， 25 \mathrm{~Hz}$ ) を図-13に示す。同図より，壁裏直近まで は実測值と解析值が比較的よく一致しているが，壁から 距離が離れると，実測值と解析值は一致せず，解析結果 の方が防振効果を過大評価していることがわかる．この 要因としては，二次元解析では遮断壁端部からの回折波 による影響が評価できないためと考えられる.

次に, 壁裏 $1 \mathrm{~m}$ における振動低減量と周波数の関係を 図-14に示す，同図より，解析值は実測值を比較的よく 再現しており，壁裏直近での防振効果については，二次 元解析で十分定量的に評価できるものと考えられる.ま た，覆工板を考慮しないモデルでも概ね評価できる可能 性が示された。

\section{5. 交通振動を対象とした防振性能確認試験}

\section{(1) 振動計測概要}

工場敷地内に設置したハイブリッド振動遮断壁の防振 効果および回折波による影響範囲を把握するため，3.(1) に示した本工事区間（設置深度7.5m，施工延長 $84.5 \mathrm{~m}$ ) の端部において，近接する在来線の列車走行時の交通振 動を利用した現場計測を実施した. 上り線軌道中心から 遮断壁までの距離は $10 \mathrm{~m}$ 程度である。ただし，遮断壁は 工場振動の低減を目的に設置されたため, 鋼矢板が振動

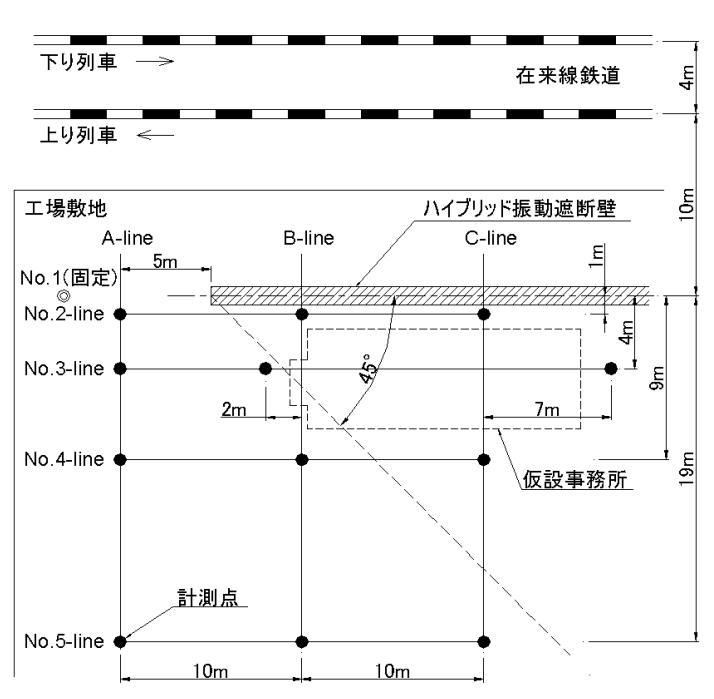

図-15 振動計測位置図（本工事区間）

発生源と反対側（工場側）に位置する.

振動計測位置図を図-15に示す。遮断壁端部からの回 折波による影響範囲が検討できるように，無対策である 測線Aと遮断壁のある測線BおよびC（計3測線）に計測 ラインを設け，固定点1箇所（No.1）および測線上4箇所 （No.2〜No.5）の計5箇所に測点を配置した. ただし， 測線BおよびCの壁から4m離れた測点（No.3）の2箇所に ついては，現場の仮設事務所が建っていた関係で，それ ぞれの測点を遮断壁の延長方向にずらした．振動計測は， 各測線毎に上り列車と下り列車について行い，列車条件 をなるべく合わすように，普通列車 (3～4両) 走行時の 振動を対象とし, 各列車の通過速度も確認した. 計測に は振動レベル計（VM-52，リオン株式会社）を使用し， 鈆直方向の振動加速度を1/500sec間隔で測定した.

\section{(2) 振動計測結果}

\section{a) 加速度波形}

振動計測結果の一例として，上り列車走行時の加速度 波形（No.2，No.5）を図-16に示す。同図より，測線Bお よびCの壁裏 $1 \mathrm{~m}$ （No.2）では，加速度振幅が大幅に低減 し，ハイブリッド振動遮断壁による防振効果が顕著に表 れていることがわかる。一方，壁から $20 \mathrm{~m}$ 程度離れた測 点（No.5）では，回折波の影響により，測線Bで振幅が 測線Aとほぼ同等となり, 遮断壁の効果がほとんど表れ ていないものの, 測線Cでは振幅が低減し遮断壁の効果 が認められる.

\section{b) 周波数特性}

上記波形の周波数分析結果を図-17に示す。測線Aの 結果に着目すると，当該地区における在来線鉄道振動は 比較的高周波振動であり，軌道近傍の測点（No.2）では 卓越周波数が20〜 $60 \mathrm{~Hz}$ 付近にあることがわかる.これは 

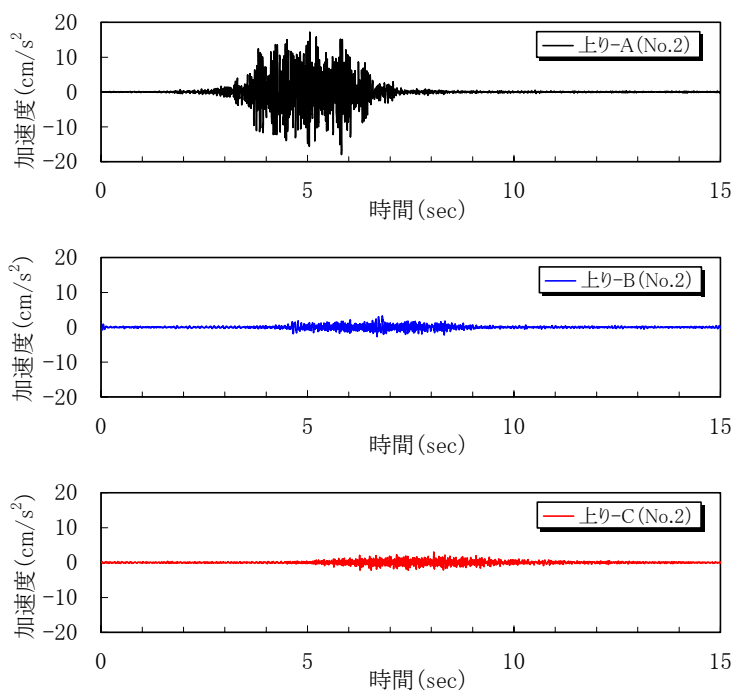

(a) No.2 測点
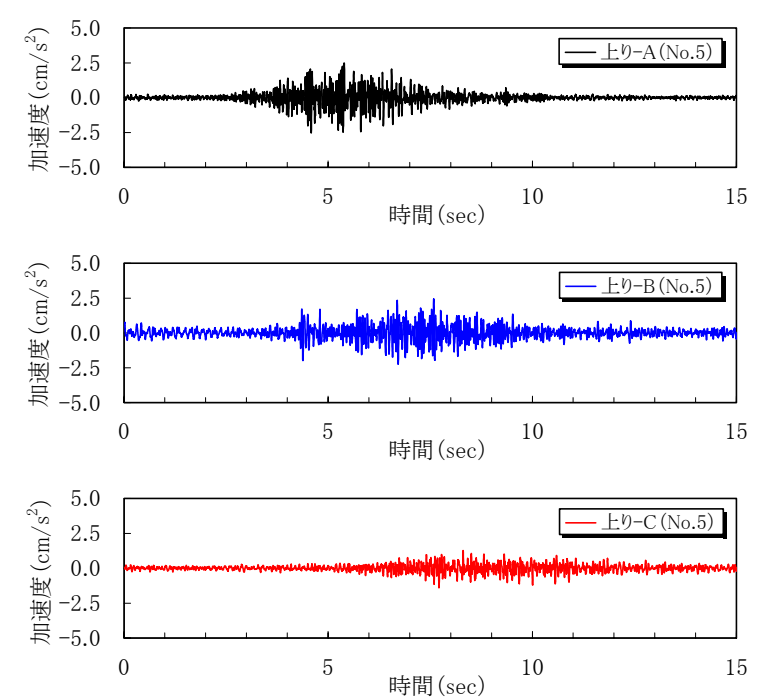

(b) No.5 測点

図-16 加速度波形 (上り列車)

既往の知見 ${ }^{2}$ とも概ね一致する。一方，軌道から $30 \mathrm{~m}$ 程 度離れた測点（No.5）では，高周波成分が減衰し，10〜 $30 \mathrm{~Hz}$ 付近が卓越している. また，八イブリッド振動遮 断壁による効果が認められる箇所では，この卓越周波数 領域で振動を大幅に低減していることも観察できる.

\section{c) 距離減衰特性}

上り列車および下り列車走行時における各測線での計 測結果を，4.(2)と同様，振動加速度レベルに換算して整 理した。 上り列車の通過速度は各々 $80 \mathrm{~km} / \mathrm{h}$ 程度，下り列 車の通過速度は各々 $70 \mathrm{~km} / \mathrm{h}$ 程度であり，上り線が測点に 近いこともあり，上り列車走行時の方が全体的に $5 \mathrm{~dB}$ 程 度大きい值となった，なお，上下線とも，各測線毎の計 測において，固定点（No.1）での振動值に大きな差異は 確認されなかった。

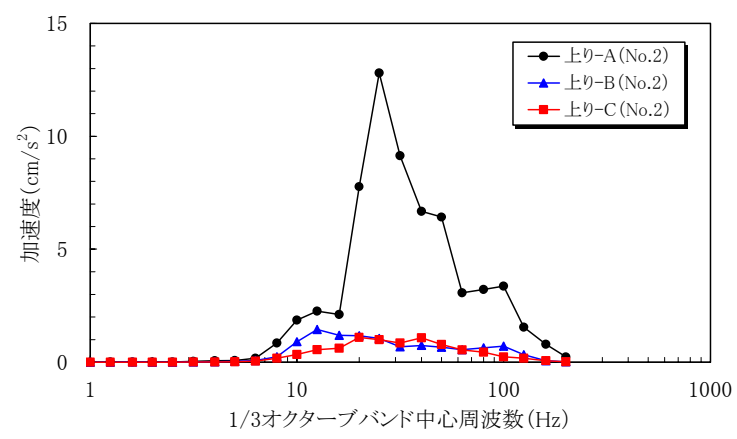

(a) No.2 測点

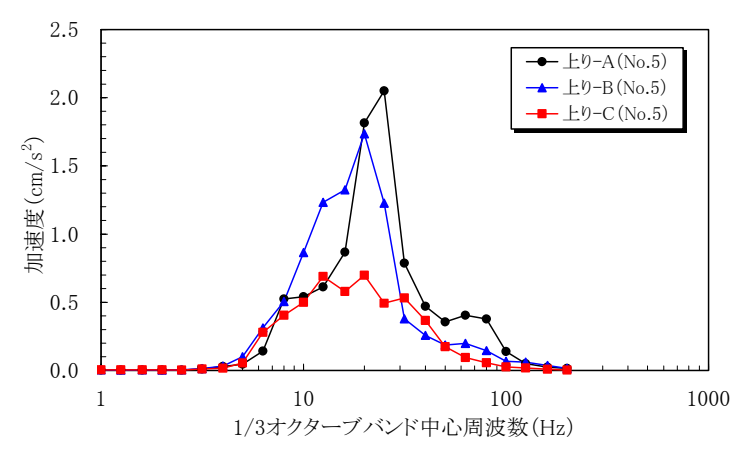

(b) No.5 測点

図-17 周波数特性（上り列車）

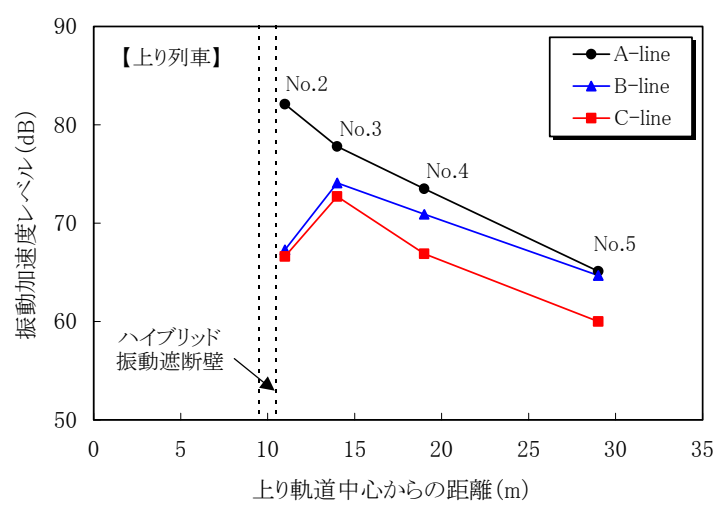

(a) 上り列車走行時

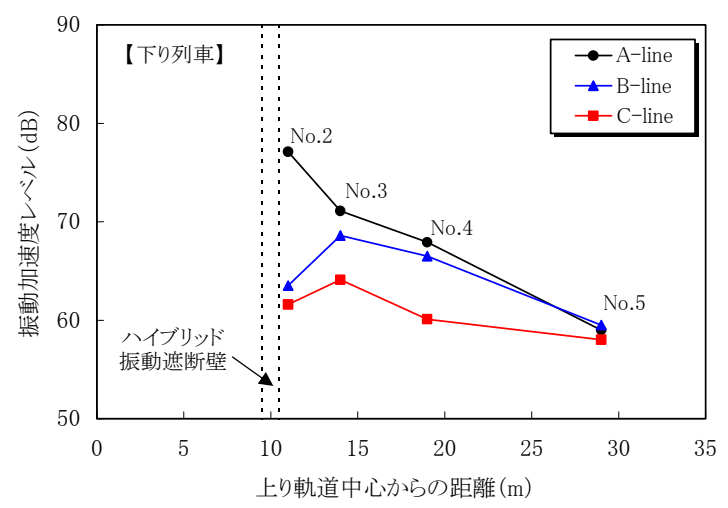

(b) 下り列車走行時

図-18 距離减衰特性 
各測線の距離減衰特性を図-18に示す。同図より，上 下線とも，壁裏 $1 \mathrm{~m}$ （No.2）での防振効果が $15 \mathrm{~dB}$ 程度で あることがわかる。また，壁の内側に位置する測線Cの 方が測線Bと比較し，防振効果の表れ方が顕著である. さらに，測線Cの壁から $20 \mathrm{~m}$ 程度離れた測点（No.5）で の結果に着目すると，上り列車に対しては $5 \mathrm{~dB}$ 程度の効 果が認められるものの，下り列車に対しては効果がほと んど認められない.このことから，振動源が移動する交 通振動では，振動源（列車や自動車）の進行方向によっ て，遮断壁端部からの回折波による影響範囲が異なるも のと推察された.

なお，本事例では，鋼矢板の位置が原則とは異なる （振動発生源側に位置しない）が，十分な遮断効果を確 認することができた.

\section{(3) 回折波の影響範囲}

遮断壁の端部において, 防振効果が明瞭に表れた範囲 $(5 \mathrm{~dB}$ 程度以上の効果が得られ，回折波による影響が比

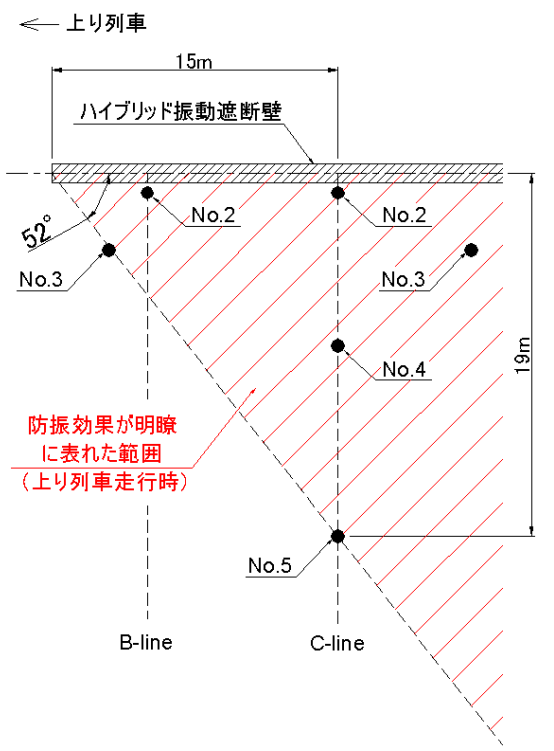

(a) 上り列車走行時

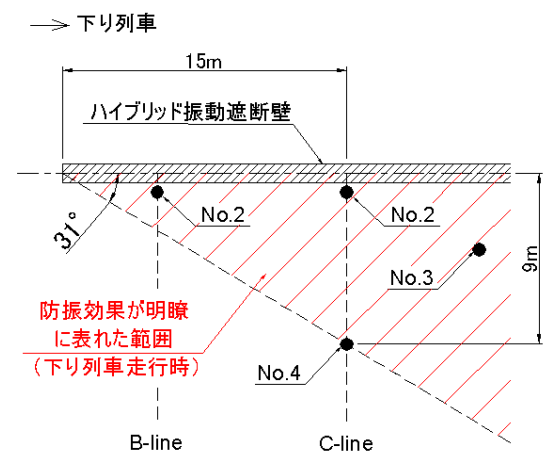

(b) 下り列車走行時

図-19 防振効果が明瞭に表れた範囲
較的小さいと判断される範囲）を，上り列車と下り列車 に分けて図-19に示す。同図より，ハイブリッド振動遮 断壁を設置したことで，壁裏付近のみならず，壁から離 れた場所においても，上り列車走行時には壁端部から50 度程度，下り列車走行時には壁端部から30度程度の範囲 で，十分な防振効果が得られているものと推測される.

振動遮断壁の設計（位置や延長の設定）を行う際，遮 断壁端部からの回折波による影響範囲を予測することは, 極めて重要な要素の一つである. そのため, 波動の回折 に関しては，これまで幾つかの研究成果が得られている. 例えば，Woods ${ }^{29)}$ は，点振源による波動の平面分布 $(360$ 度）より，振源と溝端部を延長した直線から振源を中心 に45度の範囲は，溝による効果が小さいことを示してい る.また，神田ら ${ }^{30}$ は，「概略的な検討においては，壁 から45度線の内側に位置する範囲で遮断壁の低減効果が 期待できるとして，壁の施工位置を決定することは妥当 である」としている. さらに，早川ら ${ }^{31}$ は，加振点と遮 断壁の端部を結ぶ線の端点を中心として20度程度の位置 に境界線がある（壁端部から70度程度の範囲は，回折の 影響が小さい）と考察している。，一方，芦谷 ${ }^{14)}$ は，壁が 無限長の場合の防振効果を評価した後，側方（端部）か らの回折波による効果の減少量を理論的に算出し補正す ることで，有限長の場合の効果を定量的に評価する手法 を提案している.

今回の試験結果は，まさにWoodsや神田らの研究成果 の妥当性を示すものであったと言える. すなわち，遮断 壁端部からの回折波による影響を評価する際，平面的な 振動伝搬が考慮できる三次元数值解析を活用する方法 ${ }^{21)}$ が考えられるが，簡便的に45度線を用いる方法（壁端部 から45度線の内側で振動低減効果が十分に期待できるも のとみなす方法）も有効であることが明らかとなった.

\section{6. まとめ}

本論文では，地盤環境振動対策の一手法として，ガス クッションを用いたハイブリッド振動遮断壁を取り上げ, その施工方法および防振性能について示した. 得られた 成果を要約すると以下のとおりである.

(1) 掘削時に溝壁崩壊の危険性が高い砂碟地盤を対象に, 高分子系増粘材を配合した特殊泥水を用いて溝壁の 安定を図った結果，障害物に当ることなくガスクッ ションを所定の深度に設置することができた．また， 溝壁の安定が確保できる泥水性状を確認した。

（2）起振機振動（加振周波数6 25Hz）を対象に現場計 測を実施した結果，標準施工型で設置したハイブリ ッド振動遮断壁の防振効果は，狭隘地対応型と同様， 
空溝とほぼ同等である.ただし，遮断壁の設置に伴 う位相のずれに起因し，周波数によっては，防振効 果が目減りまたは上乗せされることがある.

(3) 遮断壁の頭部処理に用いた覆工板が防振効果に及ぼ 寸影響について評価した結果, 覆工板の設置により 効果が大きく低下寸ることはない，ただし，周波数 によってその影響度合いが異なる.

（4）二次元数值解析を用いて防振性能を評価した結果, 遮断壁端部からの回折波による影響がほとんじない と考えられる壁裏直近での防振効果については，二 次元解析で十分定量的に評価できる.

（5）在来線鉄道振動（卓越周波数 $20 \sim 60 \mathrm{~Hz}$ 付近）を対象

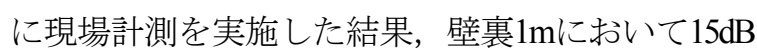
程度の効果を確認した. また, 列車の進行方向によ って，回折波の影響範囲が異なる.

(6) 遮断壁端部からの回折波による影響を評価寸る際, 概略的に45度線を用いる方法が有効である.

謝辞 : 本論文の作成にご協力いただいた（株）日建設計 シビル技術開発部の川満逸雄工学博士に深く感謝の意を 表します。

\section{参考文献}

1) 日本騷音制御工学会, 振動法令研究会 : 振動規制の手引き 一振動規制法逐条解説/関連法令・資料集一, pp.155-158, 技報堂出版，2003.

2) 地盤工学会 : 地盤環境振動の予測と対策の新技術に関する シンポジウム発表論文集，pp.16-35，2004.

3) 早川清 : 地盤振動の伝搬過程における防止対策の背景と動 向, 日本音響学会誌, 55 巻 6 号, pp.449-454, 1999.

4) 吉岡修, 芦谷公稔: 起振機実験による鋼矢板振動遮断工の 防振効果，鉄道総研報告，Vol.4，No.8，pp.51-58，1990.

5) 早川清, 原文人, 植野修昌, 丹羽誠, 庄司正弘, 西村忠 典：鋼矢板防振壁による地盤振動遮断メカニズム，地盤環 境振動の評価・予測・対策に関するシンポジウム発表論文 集, pp.79-84, 2001.

6) 吉岡修, 芦谷公稳 : コンクリート振動遮断工の防振効果, 鉄道総研報告, Vol.5, No.11, pp.37-46, 1991.

7) 橋詰尚慶，長瀧慶明，若命善雄 : 地中壁による振動低減対 策一その 1 振動調查と対策法の立案一, 第 28 回土質工学研 究発表会発表講演集, pp.1245-1246, 1993.

8) 長瀧慶明, 橋詰尚慶, 若命善雄 : 地中壁による振動低減対 策一その 2 対策工法の実施と効果の確認一, 第 28 回土質工 学研究発表会発表講演集, pp.1247-1248, 1993.

9) 早川清, 橋本佳奈, 可児幸彦 : PC 壁体の振動対策事例およ び遮断メカニズムに関する実験的考察, 第 47 回地盤工学シ ンポジウム論文集, pp.349-356, 2002.

10)神田仁, 石井啓稔, 吉岡修, 平川泰行, 川村淳一, 西村忠 典: 起振機実験および数值解析による PC 柱列壁の防振性能, 物理探查, Vol.58, No.4, pp.377-389, 2005.

11)早川清, 松井保 : EPS ブロックを用いた交通振動の軽減対策, 土と基礎，Vol.44，No.9，pp.2426，1996.

12)早川清, 中谷郁夫 : 圧縮型廃タイヤを用いた地中遮断壁に よる環境地盤振動の低減対策技術，環境技術，Vol.36，No.7， pp.27-33, 2007.

13)公害防止の技術と法規編集委員会, 経済産業省産業技術環 境局：二訂・公害防止の技術と法規（振動編）, pp.96-101， 産業環境管理協会, 1996.

14)芦谷公稔 : 振動遮断工の防振効果の評価手法, 物理探査, Vol.58, No.4, pp.351-362, 2005.

15)Massarsch, K. R. : Ground Vibration Isolation using Gas Cushions, Second International Conference on Recent Advances in Geotechnical Earthquake Engineering and Soil Dynamics, St. Louis, Missouri, Vol.2, pp.1461-1470, March, 1991.

16)Massarsch, K. R. : Vibration Isolation using Gas-Filled Cushions, Soil Dynamics Symposium to Honor Prof. Richard D. Woods (Invited Paper), Geofrontiers 2005, Austin, Texas, January, 2005.

17)大塚誠, 坪井英夫, 磯谷修二, 野津光夫, 日置和昭, 櫛原 信二 : ガスクッションを用いたハイブリッド(三重構造)振動 遮断壁工法の開発，基礎工，Vol.32，No.11，pp.81-85, 2004.

18)Kanda, H., Ishii, H., Yoshioka, O. and Hioki, K. : Field Measurement and its Analysis of "Hybrid Vibration Isolation Wall" Using Gas Cushions, The 2005 Congress and Exposition on Noise Control Engineering (INTER NOISE), CD-ROM, 2005.

19)日置和昭, 櫛原信二, 坪井英夫, 西村忠典 : 都市部におけ る低周波振動問題とガスクッションを用いたハイブリッド 遮断壁の提案，土と基礎，Vol.53，No.10, pp.17-19, 2005.

20)櫛原信二, 野津光夫, 日置和昭 : ガスクッションを用いた ハイブリッド遮断壁の鋼矢板仕様に関する一考察, 第 41 回 地盤工学研究発表会発表講演集, pp.2391-2392, 2006.

21)日置和昭，櫛原信二，野津光夫，坪井英夫，西村忠典，庄 司正弘 : 現場計測と 3 次元数值解析によるガスクッション製 防振壁の防振性能評価，土木建設技術シンポジウム論文集， pp.59-66, 2006.

22)櫛原信二, 野津光夫, 日置和昭, 神田仁 : ガスクッション を用いたハイブリッド遮断壁工法の開発と周辺地盤への影 響, 第 40 回地盤工学研究発表会発表講演集, pp.2077-2078, 2005.

23)地盤工学会 : 地盤工学・実務シリーズ 20 地中連続壁工法, pp.171-189, 2004.

24)高橋聡, 小林一男, 佐久山晋 : 泥水シールド工法における 崩壊性地盤での泥水の役割と必要性能一その 1 崩壊性地盤に おける逸泥の問題と対策一, 土木学会第 58 回年次学術講演 会講演概要集, pp.249-250, 2003.

25)平岡成明 : 地中連続壁の安定液, pp.224-232, 山海堂, 1991.

26)吉岡修, 石井啓稔, 神田仁, 庄司正弘, 西村忠典, 日置和 昭 : 2 次元数值解析を用いた空溝の防振効果に関寸る一考察, 土木学会第 60 回年次学術講演会講演概要集, pp.351-352, 2005.

27)日本建設機械化協会 : 建設工事に伴う騒音振動対策ハンド ブック（改訂版），pp.42-43，技報堂，1987.

28)中野有朋 : 環境振動, p.7, 技術書院, 1996.

29)Woods, R. D. : Screening of surface waves in soil, Journal of the Soil Mechanics and Foundation Division, ASCE, No. SM4, Proc. Paper 6031, pp.951-979, July, 1968.

30)神田仁, 加藤政史, 石井啓稔, 吉岡修 : 振動遮断壁 - 遮断 溝の防振特性に関寸る 3 次元数值解析, 物理探査学会第 114 回学術講演会論文集, pp.230-233, 2006.

31)早川清, 中谷郁夫，緒方広泰，前育弘：EPS 合成遮断壁によ る地盤振動遮断効果とその評価法の提案, 土木学会論文集 G, Vol.63, No.2, pp.138-148, 2007. 


\title{
CONSIDERATIONS ON APPLICATION OF HYBRID-TYPE VIBRATION ISOLATION WALL FOR ENVIRONMENTAL GROUND VIBRATION ISOLATION METHOD
}

\author{
Shinji KUSHIHARA, Makoto OTSUKA, Hisashi FUKADA \\ and Kiyoshi HAYAKAWA
}

The hybrid-type vibration isolation wall using gas cushions is a new technology to isolate against the propagation of environmental ground vibrations. This type vibration isolation wall is one of the vibration isolation methods by constructing the open trench-type wall of the triple structure composed of gas cushions, soil cement walls and steel sheet piles in the ground. This vibration isolation wall can be expected to have same effect with open trenches that is considered to be the most effective means.

Firstly, the authors described in this paper that the new applicable construction method when the ground construction conditions are not severe. Then, the vibration isolation performance of this hybridtype wall is examined by field measurements with a vibration exciter and the railroad traffic vibration. Also, the vibration isolation mechanism is confirmed by the two dimensional FEM analysis. 